【法】(1)基礎的検討として生理食塩水，オリーブオイル， $\mathrm{T}_{2}$ 值の異 なる各Gd-DTPA水溶液を用いたファントムを作成LSSFSE法のTE, thicknessを変化させ $\mathrm{T}_{2}$ 緩和短縮効果等をSNR, CNRにて検討. (2) 臨 床画像においてGd-DTPAを使用した場合にTE，thicknessを変化させ 膵胆道系のSNR, back ground とのCNRを検討。(3) 䠛床画像に执い てGd-DTPA未使用時と使用時におけるMRCP画像をCNR, profile curveにて比較検討.

【結果】(1)TEを長くするほど各試料のSNRは低下した。しかし，GdDTPAの血中濃度に值する Gd-DTPA0.1 $\mathrm{mmol} / 1$ 水溶液 $\left(\mathrm{T}_{2}\right.$ 值：約 $80 \mathrm{~ms}$ ) OSNRはTE約700ms以上で平衡状態となり生理食塩水とのCNRも大 きな低下はなかった， thicknessは，厚くするほど全体にSNRは上昇 LCNRは若干低下した。(2)TEは約600ms以上でback groundのSNRが 低值となり，膵胆道系のSNR，CNRはTEを長くするほど低下した。

(3)Gd-DTPA使用時では未使用時に比べて膵胆道系のSNR，CNRと も上昇して, back ground noiseのばらつきも大幅に滅少した。

【考察】SSFSE thick-slice MRCPは, Gd-DTPAの $\mathrm{T}_{2}$ 緩和短縮効果を用 いることにより back ground noiseを大幅に抑制することが可能であ り，TEの短縮やthicknessを増大することが可能であった。

\section{MR hydrometryの基碟的検討}

山梨医科大学医学部附属病院·放射線部 相川良人, 熊谷博司

舘田良仁，佐野尚樹，新井誉夫，秋山三郎，佐野芳知

GE横河メディカルシステム(株) 椛沢宏之

【目的】MR hydrometryはMR画像を用いて, 水の信号から液体量の推 定を行う方法である. 呼吸停止下での管腔内の水信号をきわめて強 いT強調により画像化する方法は, 上腹部においてはMR cholangiopancreatography (MRCP) として広く臨床応用されている. single shot 系の撮像法の進歩により, 単に管腔内の水信㕺の形態情報ばかりで なく, 動態情報, 機能情報をも得られるようになった。今回, 管腔 内の体液量の測定を目的としてMR hydrometryの基礎的検討を行っ た。

【方法】使用装置はGE社製Signa MR/i(1.5T)，およびAdvantageworkstation3.1，撮像シーケンスはsingle shot fast spin echo(SSFSE) 用いた。自作ファントムにより実際の水の量とMR hydrometryによ り推定した量の相関について, 水の量の变化, 撮像条件を変えて測 定する。

【結果】ファントムでの実験において，MR hydrometryにより推定し た量は，実際の水の量に対して正の相関を示した。 また水の量の増 加に対しては直線性を示した。

【結諭】今回の結果より, 体幹部の管腔内液体量推定の可能性が示唆 された，セクレチンを付加した膵液分泌量の測定等に臨床応用が可 能である。

227 未破裂脳動脈瘤のGuglielmi's detachable coil(GDC) 塞栓療法 前のMRAによる血管内視像の有用性

金沢大学大学院·医学系研究科 山本敏信

金沢大学医学部保健学科 武村哲浩

【目的】脳動脈瘤のIVR治療に際して動脈瘤の形態や，周囲動脈との 関係の把握は重要で, 今回MRAおよびその血管内視像を施行し，そ れらの有用性を retrospectiveに評洒した。

【対象および方法】MRAおよび血管造影が施行された未破裂脳動脈瘤 患者 6 例 7 部位を対象とした。 その内訳は中大脳動脈分岐部 2 例 3 部位，その他 4 部位である。また 1 部位はGDC治療が行えなかっ た. MRAは全例で3D-TOFを施行し，3例で造影MRAを追加した。 このデータをSUN Workstation (GE社製Advantage Windows Ver3.1)に 転送し処理を行った. MRAはhigh definition MIP, multiprojection volume reconstruction(MPVR)を行い，血管内視像はNavigation smooth を使い，適切な信号強度および視野角を設定し，周囲血管がすべて
観察できるように，親動脈から動脈瘤をみた像，動脈瘤内から動脈 瘤頸部をみた像, 末梢動脈から動脈瘤をみた像を可能な限り得るこ とを試み，動脈瘤頸部のくびれ，動脈瘤自体もしくは頸部のごく近 傍から分岐する血管の有無などMRAに付加する情報の存在を調べ た。

【結果】7 部位で動脈瘤頸部のくびれの存在を確認でき，治療不能の 1 部位では動脈瘤内から分岐する血管を確誌できた，動脈瘤頸部近 傍からの分枝がみられた 1 例では，慎重な治療操作にもかかわらず GDC治療後に血管支配領域の梗塞を来した。

【結論】retrospective studyであるがMRAおよびその血管内視像は動脈 瘤と親血管との関係，周囲血管の分岐状態の把握に優れており，末 破裂脳動脈瘤のGDC治療の術前評価に有用と考えられる。

228 3D MRAにSORSパルスを併用し頸部血管撮像における描出 能の検討

東邦大学医学部付属大森病院 -中央放射線部 大橋直樹, 大久保卓史 小島治朗，菊池英夫/東芝メディカ儿(株） 松原智子，廣瀬久美子

【目的】頸部血管撮像法の一つである3D-TOF法について，描出能の検 討を行った。

【使用機器】東芝製 1.5T MRI EXCELART(Pianissimo)

【方法】3D-TOF法について頸部動脈の撮像を行った際の描出能向上を 目的として, 静脈信号, 背景信号の抑制に着目した. 3D-TOF法に,

Pre-Saturationパルス・SOR-STCパルスを併用した摄像を行い，描出 能の比較検討を行った。

【結果】SORSパルスは，血流信号に影響を与えることなく，背景信 号を除去することができ，同時に静脈からの信号を抑制することが できる、最適化したSORSパルスを3D-TOF法と併用することによ り，頸部血管の描出能を向上させることが可能であると思われた。

229 motiontrack coronary angioに扔ける撮像時間短縮の試み 東海大学医学部付属病院・放射線技術室 古川友, 室伊三男 池田 秀，田島隆人，原口信次

【目的】一般的にmotiontrack coronary angio（以下，MCA)は，撮像時 間が長いことが問題となっている. 今回われわれは, segment数と tracking windowの幅を変化させ，撮像時間が画像に与える影響につ いて検討したので報告する.

【方法】検討する項目として, tracking windowを20mmで固定し, segment数を $10 ， 16 ， 26$ と変化させたものと, tracking windowを $5 \mathrm{~mm}$ で固定Lsegment数を同様に変化させたものを，健常人ボランティア を用いて比較した。

【使用機器】Philips社製 GYROSCAN ACS-NT PT 6000(1.5T)

【結果】tracking window $5 \mathrm{~mm}$ と20mmでは，呼吸の動きによる画像の 変化は認めなかった。 また， segment数を16，26と変化させたが，心 臟の動きによる画像上の有意差は認められなかった。

【考察】上記よりMCAの撮像時間短縮は可能であり, 呼吸停止の困難 な患者においても摄像が可能である。また, 放射線被曝がないこと から, 小児冠動脈疾患(川崎病)の検査や，造影荗の使用が困難な患 者等の検查も十分可能と考える。

\section{0 小児における心大血管造影3D-MRA}

岩手医科大学附属循環器医療セン夕一・放射線室 平田洋介

【目的】小児の心奇形および大血管系の検査方法は従来，X線を利用 した心臓カテーテル検查で行われている。カテーテル検査時には， 抑制のために全身麻䣷を施行したり，透視下でカテーテルを鼠径部 から大動脈まで挿入するのでX線被曝と身体的負担が生じ患者に とって侵襲性の高い検査方法である。 そこで今回, 全身麻酔を必要 とせず末梢血管から造影可能な低侵襲的検査方法の造影3D-MRAで 小児の心大血管について検討を行った。 
【使用機器】Signa Horizon Echospeed LX Ver.8.3m5 (GE), ソニック ショット 50 (根本杏林堂), Magnevist (SCHERING), Pulse Oximeter Model 3500(MRE)

【検討方法】(1) 造影3D-MRAの撮像パラメータの検討. (2) 造影夕イ ミングの検討.

【結論】造影3D-MRAはX線心臓カテーテル検査と比べ検查時間が短 くまま末梢血管より鎮静剂を投与したり造影剤の注入を行うので 患者の身体的負担が軽減された。.3D-MRAは 1 回の造影検査で病変 部が三次元で描出が可能になり多方向の画像で観察できた．以上の 結果より造影3D-MRAは心大血管疾患には有用な低侵襲的な検査方 法と思われる。

231 all gradients rephased FFE法を用いた非造影MRAの試み 倉敷中央病院・放射線センタ一 田㴊 隆，光井英樹，森本規義 熊代正行，中田和明，高越浩一，中川 忍，古牧伸介，清野 隆 【目的】心藏MR cineの撮像法として知られる 3 軸すべてのグラディ エントに対し位相補正を加えた高速FE法は高い信号強度を得ること ができる，血液も例外ではなく，心蔵MR cineにおいて明らかにさ れている，今回われわれはこの撮像法を用いて，腎動脈を目的とし た非造影MRAの可能性について検討した。

【方法】この高速FE法 (balanced FFE)の最適条件を，ファントムおよ びボランティアにて，1．flip angle (FA)，2．脂肪抑制，3，k-空間 への充填方法，を検討項目として求めた．また，臨床において造影 MRAと併用し，描出能について検討した.

【使用装置】PHILIPS Gyroscan Intera

【結果】1. 今回，TR/TEは，流れ，動きを考慮して装置の竍す最短值 とした．2，FAは大きくなるほど信号強度は向上するがSARを考慮 して60度とした３．細い血管の描出には脂肪抑制が必須であっ た。脂肪抑制法として1-1 binomial pulseを用いた水選択励起法を用 いた．4．k-筀間への充填方法は，セントリックオーダでは血液信号 のムラとゴーストがみられたため，脂肪抑制併用時においてもリニ アオーダとした，以上より臨床応用する撮像条件をFOV $350 \mathrm{~mm} / \mathrm{TR}$ 3.5/TE 1.75/FA 60/slice 5mm/-2mm gap 36枚, 脂肪抑制俾用時：FOV $350 \mathrm{~mm} / \mathrm{TR}$ 6.4/TE 3.2/FA 60/slice $5 \mathrm{~mm} /-2 \mathrm{~mm}$ gap 36枚とした. 5. 臨 床においては磁場の不均一による信号の劣化はあったが，造影MRA と同等の描出能が確認された。

【まとめ】balanced FFEは十分臨床応用可能であり，脂肪抑制法を含 め，さらに検討することによりさまざまな部位への応用も示唆され た.

232 SuperFASE法を用いた非造影下肢MRAの至適撮像法の検討 一第 1 報 FBI法とSPEED法の応用一

岡山光生病院·放射線部 小橋泰之, 小野 敦, 高田 悟, 林由佳子 長町孝章，近藤且久，藤井 隼人

【目的】SuperFASE法を用いた下肢MRA画像に扔いて，動静脈分離能 がより向上する方法を検討し，良好な結果が得られたので報告す る.

【使用機器】使用装置一東芝社製 FLEXART/Hyper (0.5T)

【方法】FBI法にてTEを39，78，130，247，494msecに変化させ，位相 方向H-Fで撮像を行った．次に同条件にて位相方向R-Lで撮像を行な い，得られた画像より，1）H-F方向の画像における搪張期と収縮期 のsubtraction画像，2) R-L方向の画像に扔ける拡張期と収縮期の subtraction画像，3）1），2）のsubtraction画像をaddition処理した画像, をそれぞれ作成し，動静脈分離能について比較検討を行った。

【結果】すべての画像において，血流速度の速い主要血管描出能は， TE39msec，78msecで良好だった，血流速度の杽い末梢側血管描出能 はTE78msec, 130msecで良好たっった。TE494msecでは血管描出能は 優れていなかった１）のsubtraction画像では，H-F方向に平走する主
要動脈描出能は向上したが, 同方向の末梢側動脈描出能は低下し た。 R-L方向に平走する末梢側動脈描洲能は向上した。2)の subtraction画像では，H-F方向に平走する主要動脈描出能は低下した が, 同方向の末梢側動脈描出能は向上した，R-L方向に平走する末 梢側動脈描出能は低下した．3）1），2)のaddition画像では，H-F・RL方向でそれぞれ描出不良であった血管像が明瞭に描出され，すべ ての動脈血管に扔いて描出能の向上が認められた。

233 脂肪抑制併用elliptical centric view orderingの基礎的検討 横浜栄共済病院・放射線科 高橋光幸, 荒田光俊, 森 直彦 畑中干代，山之稔/杏林大学・放射線医学教室 高原太郎 GE横河メディカルシステム・技術開発センター 松田 豪 【目的と背景】頭頸部の造影MRAは3D-TOF SPGRに㧍ける elliptical centric view ordering (以下, ECVO法)を用いて撮像されている. 従来 ではECVO法と脂肪抑制パルスとは併用できなかった。今回われわ れは脂肪抑制付加ECVO法の撮像が可能となったことから，ファン トムを用いて脂肪抑制効果の検誩学衍った。

【方法】ファントム：サラダオイル，生食水， $2 \mathrm{mmol} / \mathrm{l}$ に調製したGdDTPA 計 3 種. 使用機種: GE-YMS 1.0T Signa MR/i Hispeed ver8.3M5. 撮像シーケンス : irelliptic (3D-TOF SPGR法with ECVO法 with 脂肪抑制パルス). 脂肪抑制パルス：脂肪のみ選択的に-180度 励起しTI時間待ったのちに撮像開始するSpec IR法。撮像パラメー 夕 : TR/TE/FA 5.4/1.3/20․ TI : 21〜27msまで 3 種, t1 FAT10〜260 まで14種

(1)(a) irellipticの可変パラメータであるt1FATを変化させて, 脂肪抑制 効果の検討を行った（b) irellipticの可変パラメータであるTIを変化 させて, 脂肪抑制効果の検討を行った. (2) conventional centric view ordering (以下, CCVO法)を用いた方法で同一条件 (Spec IR法付加)で 撮影し，画像を比較検討した。

【結果】(1)(a)撮像スラブ中心部に扔けるサラダオイルファントムの信

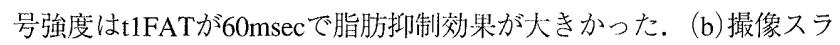
ブ中心部に抬けるサラダオイルファントムの信号強度はTIが $21 \mathrm{msec}$ で脂肪抑制效果が大きかった。 (2) 脂肪抑制併用ECVO法はSpec IR法 を用いたCCVO法と比較して脂肪抑制效果は不良であった.また脂肪 抑制併用ECVO法で撮像された画像は位相方向にアーチファクトを 生じた。

【考察・まとめ】irellipticの可変パラメータであるt1FAT, TIを変化さ せることで脂肪抑制効果は変化した。したがって臨床に用いる際は 撮像部位ごとに至適撮像条件を求めておくことは重要であると考え られた. irellipticは 1 回の脂肪抑制パルスを付加するため低周波成 分においては脂肪信号が抑制されているが，高周波成分に向かって 脂肪信号が回復する。したがって位相方向にアーチファクトが生じ たのはk空間上での信号の不連続性のためであると推測された。臨 床においても阔様な現象が考えられるため注意が必要であると考え られた。

234 elliptic centric法に抢ける脂肪抑制(Spec-IR)の基礎的検討 日本医科大学付属病院・放射線科 土橋俊男，岩崎 淳、森 克彦 鈴木 健/GE横河メディカルシステム(株) 松田 豪

【目的】k-spaceの低周波成分からデー夕を充填するelliptic centric法 は，造影剤を使用する3D-MRAにおいて多用されている，しかしな がら, 従来のk-spaceの充填方法と買なるため, 高速脂肪抑制法(数 回のTRに一度の割合で脂肪抑制pulseを印加する手法：Spec-IR）が使 用できないという欠点がある。今回われわれは, elliptic centric法に Spec-IRの併用を可能にしたsequence (fast SPGR)を用いて, 脂肪抑制 効果について基礎的な検討を行った。

【万法】ファントムとして塩化ニッケル水溶液とベビーオイルを使用 し, Spec-IR pulseの印加回数を変化して, 雨者の信号強度比(ベビー 